\title{
TLR4 polymorphisms seem not to be associated with prediabetes and type 2 diabetes but predispose to diabetic retinopathy; TLR4 polymorphisms in glucose continuum
}

\author{
${ }^{1}$ Zaharieva ET, ${ }^{1} \mathrm{KamenOV}$ ZA, ${ }^{2}$ Savov AS \\ ${ }^{1}$ Clinic of Endocrinology, Alexandrovska University Hospital, Department of Internal Medicine, \\ Faculty of Medicine, Medical University-Sofia, Sofia, Bulgaria \\ ${ }^{2}$ National Genetic Laboratory, Department of Obstetrics and Gynecology, Faculty of Medicine, \\ Medical University-Sofia, Sofia, Bulgaria \\ E-mail: zaharieva_e@abv.bg
}

Objectives. Compared to type 1 diabetes, the role of the immune and autoimmune pathogenetic mechanisms is much less studied in the type 2 diabetes. Toll-like receptors 4 (TLR4) have a leading role in inflammation, insulin resistance, and vascular damage. This study aimed to analyze the relationship between the polymorphisms in TLR4 gene and different stages in the glucose continuum from prediabetes to the type 2 diabetes and chronic microvascular complications.

Materials and Methods. The study included 113 patients with the type 2 diabetes, 29 participants with prediabetes, and 28 controls. Polymerase chain reaction (PCR) was used for genotyping Asp299Gly and Thr399Ile polymorphism, followed by restriction analysis.

Results. The difference in the genotype frequency for both polymorphisms in patients with the type 2 diabetes or prediabetes compared to that in controls was not significant. Patients with heterozygous genotype of Asp299Gly polymorphism had a higher prevalence of diabetic retinopathy (42.9\%) than participants with homozygous genotype (9.0\%) (OR [95\%CI] $=7.61$ [1.41-41.08]; $\mathrm{p}=0.018$ ). No association was established for diabetic polyneuropathy and nephropathy. Prevalence of chronic diabetes complications was not related to Thr399Ile polymorphism.

Conclusion. Our study demonstrates that Asp299Gly and Thr399Ile polymorphisms seem not to be associated with the type 2 diabetes and prediabetes but Asp299Gly may contribute to diabetic retinopathy predisposition.

Key words: type 2 diabetes, prediabetes, diabetic complications, toll-like receptor 4 , single nucleotide polymorphism, innate immune response

Having in mind the insidious development of the type 2 diabetes (T2D), the difference in the evolution of any of its complication and the principle "the earlier, the better the treatment", it is important to identify the predisposing factors for their progress.

Compared to the type 1 diabetes (T1D), the role of immune and autoimmune pathogenetic mecha- nisms is much less studied in T2D. During the last decades the scientific interest has been broadened to the earlier stages in the glucose continuum and development of the disease - risk factors and prediabetes. Nonspecific immune system participates actively in the pathogenesis of obesity and metabolic syndrome (Festa et al. 2000). T2D is considered to be a state,

Corresponding author: Dr E. Zaharieva, Clinic of Endocrinology, Alexandrovska University Hospital, 1 Georgy Sofiiski Str, 1431 Sofia, Bulgaria; phone: +359 8833401 34; fax: +3592 9230 275; e-mail: zaharieva_e@abv.bg. 
characterized by chronic low-grade inflammation (Spranger et al. 2003). One of the pathways for initiation of innate immune response is through toll-like receptors (TLRs). They are pattern recognition receptors (PRRs), which recognize antigens with repeated pathogen-associated molecular patterns (PAMPs). Their activation induces a cascade signaling with a final effect - transcription of genes of inflammatory cytokines through the NFkB pathway (Kawasaki and Kawai 2014). Cytokines are involved in phosphorylation of insulin receptor substrates and further changes in post-receptor signaling. Thus TLR2 and TLR4 have been implicated to participate in progress of insulin resistance (Shi et al. 2006). Hyperglycemia is associated with their stimulation (Dasu et al. 2008) and studies have demonstrated they are overexpressed in patients with diabetes - both the type 1 (Devaraj et al. 2008) and the type 2 (Dasu et al. 2010).

$\mathrm{T} 2 \mathrm{D}$ is a polygenic disease and the presence of a variety of polymorphisms seems to be altering the risk of the disease when external factors interfere. As the immune system actively participates in its pathogenesis, polymorphisms in the genes encoding innate immune response factors have been researched for a predisposing role - C-reactive protein (CRP) (Wolford et al. 2003), tumor necrosis factor alpha (TNFa) (Fernandez-Real et al. 1997), interleukin 6 (IL-6) (Illig et al. 2004), plasminogen activator inhibitor-1 (PAI-1) (Hoffstedt et al. 2002), transforming growth factor beta (TGF $\beta$ ) (Rosmond et al. 2003), etc.

TLR4 gene, encoding TLR4, has also been evaluated as a risk factor for T2D (Bagarolli et al. 2010). Products of its transcription actively participate in the innate immune response in the metabolic syndrome and induction of insulin resistance (Weyrich et al. 2010). As hyperglycemia also contributes to immune system activation through oxidative stress products, advanced glycation end products (AGEs), etc. (Forbes and Cooper 2013), polymorphisms in TLR4 gene are also potential predictors for the risk of chronic complications of diabetes.

Research on TLR4 gene has described a number of nonsynonymous polymorphisms. A population frequency exceeding $5 \%$ has been shown for two - one with a nucleotide sequence, leading to the exchange of the amino acid Aspartate with Glycine on 299th place of the encoded peptide (rs4986790), defined by $A$ and $G$ alleles respectively, and the other leading to replacement of Threonine with Isoleucine on 399th place (rs4986791) of the peptide structure (Ferwerda et al. 2008), defined by $\mathrm{C}$ and $\mathrm{T}$ allele, respectively.

According to the NCBI HapMap database, the allele frequency of rs4986790 in European studies varies between 0.9499 and 0.9666 for allele $A$, and between 0.0500 and 0.0333 for allele G. Concerning rs4986791, the allele frequency for the wild allele $\mathrm{C}$ varies between 0.9499 and 0.9553 , and between 0.5000 and 0.0446 for T allele, respectively.

Both genetic variants have been related to altered responsiveness to ligands (Arbour et al. 2000) and thus have become the subject of many studies exploring genetic background of diseases (Noreen et al. 2012).

The aim of this study was to characterize the association between Asp299Gly and Thr399Ile polymorphisms of TLR4 gene and presence of T2D and prediabetes in a sample of Bulgarian population and to describe their relation to chronic diabetic complications.

\section{Subjects and Methods}

The protocol of the study was in accordance with the declaration of Helsinki and was approved by the ethics committee of Medical University-Sofia. All participating subjects signed a written informed consent. The study included 113 patients with T2D and 29 subjects with prediabetes (14 with impaired fasting glucose and 15 with impaired glucose tolerance), all diagnosed according to criteria of the American Diabetes Association (ADA, 2010). The control group consisted of 28 clinically healthy volunteers. Exclusion criteria were duration of diabetes more than 10 years, T1D, malignant and acute or chronic inflammatory diseases, estimated glomerular filtration rate (eGFR) $<60 \mathrm{ml} / \mathrm{min} / \mathrm{m}^{2}$, pregnancy. Fasting plasma glucose (FPG) and postprandial plasma glucose (PPG) - two hours post lunch meal, HbA1c of the enrolled subjects were assessed by standard laboratory techniques in the Central Laboratory of the Alexandrovska University Hospital, which is the referent one for Bulgaria. Diabetic polyneuropathy was assessed semiquantitatively through Neuropathy Disability Score (Weintrob et al. 2007; Yang et al. 2014). Fundoscopy for diabetic retinopathy was performed by an ophthalmologist. EGFR was calculated through The Modification of Diet in Renal Disease (MDRD) formula: $186 \times(\text { Creatinine, } \mu \mathrm{mol} / 1 / 88.4)^{-1.154} \times$ (Age $)^{-0.203}(\times(0.742$ for women $)$.

Genotyping. High molecular weight DNA was extracted from nuclear blood cells for genetic analysis. Blood was obtained in a plastic tube with K3 EDTA (Ethylenediaminetetraacetic acid) as an anticoagulant. Blood was kept at $+4^{\circ} \mathrm{C}$ for maximum 48 hours. The salting out protocol of Miller et al. (1998) was used for the extraction of genomic DNA. 
The polymorphic region of the TLR4 gene was amplified by polymerase chain reaction (PCR) with the following primer sets as described by Nyati et al. (2010):

TLR4 Asp299Gly - Forward 5' GATTAGCATACTTAGACTACTACCTCCATG 3'

Reverse 5' GATCAACTTCTGAAAAAGCATTCCCAC 3';

TLR4 Thr399Ile - Forward 5' GGTTGCTGTTCTCAAAGTGATTTTGGGAGAA 3'

Reverse 5' ACCTGAAGACTGGAGAGTGAGAGTTAAATGCT 3'.

The PCR was performed in a reaction volume of $15 \mu \mathrm{l}$ containing $10 \times$ PCR buffer, $200 \mu \mathrm{M}$ each of the dNTPs, $2 \mathrm{mM}$ of $\mathrm{MgCl}_{2}$, 15 pmol of each primer, $1.25 \mathrm{U}$ of Taq DNA polymerase and 100 ng of genomic DNA as a template. PCR amplifications were performed in a thermocycler with an initial denaturation at $94^{\circ} \mathrm{C}$ for $5 \mathrm{~min}$. The thermal cycle was repeated 30 times: denaturation at $95^{\circ} \mathrm{C}$ for $30 \mathrm{~s}$, annealing for $60 \mathrm{~s}$ at $53^{\circ} \mathrm{C}$ for Asp299Gly and at $60^{\circ} \mathrm{C}$ for Thr399Ile, and extension at $72^{\circ} \mathrm{C}$ for $60 \mathrm{~s}$. A final extension of five minutes at $72^{\circ} \mathrm{C}$ followed. PCR product was $249 \mathrm{bp}$ (base pairs) for Asp299Gly and 407 bp for Thr399Ile.

TLR4 Asp299Gly polymorphisms were detected through Nco I restriction endonuclease. Restriction was performed overnight at $37^{\circ} \mathrm{C}$, fragments were separated through $3.0 \%$ agarose gel electrophoresis.

TLR4 Thr399Ile polymorphisms were detected through Hinf I restriction endonuclease. Restriction was performed overnight at $37^{\circ} \mathrm{C}$, fragments were separated through $2.5 \%$ agarose gel electrophoresis. Recognized sequences and restriction fragments are presented on Table 1.

Statistical analysis. Statistical analysis was performed with SPSS 19 Statistics Package (Chicago, Illinois). Chi square test or Fisher exact test were used for assessing differences in frequencies between groups. Odds ratio (OR) with confidence interval (CI) of 95\% have also been calculated. Student's t-test or nonparametric Mann Whitney U test were used for assessing data between independent samples. $P$ values less than 0.05 were considered significant.

\section{Results}

Clinical and laboratory characteristics of the participants are presented in Table 2. Gender distribution between diabetes $(57.5 \%, \mathrm{n}=65)$ and control groups $(46.2 \%, n=13)$ did not differ significantly $(\mathrm{p}=0.291)$, but the percentage of women $(86.2 \%, n=25)$ enrolled with prediabetes exceeded that in the other two groups $(\mathrm{p}<0.005)$.

Genotypes did not differ significantly from expected by Hardy-Weinberg equilibrium in neither group (T2D: $\mathrm{p}=0.696$ for Asp299Gly and $\mathrm{p}=0.581$ for Thr299Ile; prediabetes: $\mathrm{p}=0.768$ and $\mathrm{p}=0.064$; control group: $\mathrm{p}=0.845$ and $\mathrm{p}=0.838$, respectively for both polymorphisms).

A significant difference in the allele and genotype frequency of Asp299Gly and Thr399Ile polymorphism in TLR4 gene in patients with T2D and prediabetes compared to controls was not found (Table 3 ). All participants who had the G allele for Asp299Gly were also heterozygous for Thr399Ile polymorphism. Three patients with T2D were heterozygous for Thr399Ile only. We did not find a homozygous genotype for the recessive alleles of both analyzed polymorphisms within the T2D group. Only one patient with prediabetes was homozygous for the recessive allele of Thr399Ile polymorphism.

T2D patients with homozygous and heterozygous genotype of Asp299Gly polymorphism had non-significant difference in age $(53.07 \pm 7.36$ vs. $54.25 \pm 7.19$ years), diabetes duration $(4.35 \pm 2.92$ vs. $3.13 \pm 3.03$ years), glycemic control (HbAlc $=8.04 \pm 1.92$ vs. $9.00 \pm 1.32 \%, F P G=8.13 \pm 3.01$ vs. $7.64 \pm 3.22 \mathrm{mmol} / \mathrm{l}$, $\mathrm{PPG}=8.01 \pm 3.22$ vs. $9.77 \pm 5.23 \mathrm{mmol} / \mathrm{l}$ ), weight (BMI=32.62 \pm 6.96 vs. $30.31 \pm 7.51 \mathrm{~kg} / \mathrm{m}^{2}$; waist circumference $=103.16 \pm 15.38$ vs. $99.43 \pm 16.92 \mathrm{~cm}$ ), systolic $(133.57 \pm 20.27$ vs. $132.50 \pm 20.53 \mathrm{mmHg})$ and diastolic blood pressure $(83.00 \pm 10.30$ vs. $80.00 \pm 5.35 \mathrm{mmHg})$. For Thr399Ile polymorphism homozygous (CC) and heterozygous genotypes (CT) were also not associated with a difference in age $(53.09 \pm 7.40$ vs. $55.64 \pm 6.78$ years), diabetes duration $(4.42 \pm 2.94$ vs. $3.05 \pm 2.70$ years), glycemic control ( HbAlc $=7.96 \pm 1.88$

Table 1

Restriction enzyme characteristics

\begin{tabular}{|c|c|c|c|}
\hline TLR4 Polymorphism & $\begin{array}{l}\text { Restriction } \\
\text { enzymes }\end{array}$ & Recognized sequences & Restriction fragments, bp \\
\hline Asp299Gly (rs4986790) & Nco I & $\begin{array}{l}\text { 5’GATTAGCATACTTAGACTACTACCTCCATG3' } \\
\text { 5'GATCAACTTCTGAAAAAGCATTCCCAC3' }\end{array}$ & $\begin{array}{l}\text { wild allele: } 249 \\
\text { recessive allele: } 223+26\end{array}$ \\
\hline $\begin{array}{l}\text { Thr399Ile } \\
\text { (rs4986791) }\end{array}$ & Hinf I & $\begin{array}{l}\text { 5'GGTTGCTGTTCTCAAAGTGATTTTGGGAGAA3' } \\
\text { 5'ACCTGAAGACTGGAGAGTGAGAGTTAAATGCT3' }\end{array}$ & $\begin{array}{l}\text { wild allele: } 407 \\
\text { recessive allele: } 378+29\end{array}$ \\
\hline
\end{tabular}

Abbreviations: TLR4 - Toll-like Receptor 4; bp - base pairs 
Table 2

Characteristics of participants

\begin{tabular}{lccccc}
\hline Parameter & $\begin{array}{c}\text { T2D } \\
(\mathbf{n}=\mathbf{1 1 3})\end{array}$ & $\begin{array}{c}\text { Prediabetes } \\
(\mathbf{n}=\mathbf{2 9})\end{array}$ & $\begin{array}{c}\text { Controls } \\
(\mathbf{n}=\mathbf{2 8})\end{array}$ & $\mathbf{P}^{*}$ & $\mathbf{P}^{\dagger}$ \\
\hline Age $(\mathrm{y})$ & $53.15 \pm 7.32$ & $50.90 \pm 8.76$ & $51.82 \pm 3.72$ & NS & NS \\
BMI $\left(\mathrm{kg} / \mathrm{m}^{2}\right)$ & $32.46 \pm 6.99$ & $35.29 \pm 6.96$ & $23.93 \pm 3.36$ & 0.000 & 0.000 \\
Waist circumference $(\mathrm{cm})$ & $102.92 \pm 15.43$ & $103.00 \pm 13.96$ & $88.57 \pm 14.49$ & 0.000 & 0.002 \\
SBP $(\mathrm{mmHg})$ & $133.50 \pm 20.20$ & $134.66 \pm 20.35$ & $119.29 \pm 15.85$ & 0.000 & 0.003 \\
DBP $(\mathrm{mmHg})$ & $82.79 \pm 10.04$ & $84.48 \pm 9.85$ & $75.00 \pm 8.82$ & 0.000 & 0.001 \\
HbAlc $(\%)$ & $8.11 \pm 1.89$ & - & - & - & - \\
FPG $(\mathrm{mmol} / \mathrm{l})$ & $8.10 \pm 3.01$ & $5.47 \pm 0.76$ & $5.29 \pm 0.52$ & 0.000 & NS \\
PPG (mmol/l) & $8.13 \pm 3.38$ & - & - & - & - \\
PG on $120^{\text {th }}$ min of OGTT & - & $7.51 \pm 1.70$ & - & - & - \\
eGFR (ml/min/1.73m $\left.{ }^{2}\right)$ & $97 \pm 25.12$ & $90.31 \pm 23.91$ & $84.60 \pm 16.20$ & 0.018 & NS \\
\hline
\end{tabular}

Abbreviations: T2D - type 2 diabetes; BMI - Body Mass Index; SBP - systolic blood pressure; DBP - diastolic blood pressure; FPG - fasting plasma glucose; PPG - postprandial plasma glucose; PG - plasma glucose; OGTT - oral glucose tolerance test; eGFR - estimated Glomerular Filtration Rate

Results are expressed as Mean \pm Standard Deviation. $\mathrm{p}^{*}$ - T2D vs. controls; $\mathrm{p}^{\dagger}$ - prediabetes vs. controls; NS - non-significant

Table 3

Allele and genotype frequencies in groups

\begin{tabular}{|c|c|c|c|c|c|c|c|}
\hline & & $\begin{array}{l}\text { T2D } \\
\text { n (\%) }\end{array}$ & $\begin{array}{l}\text { Prediabetes } \\
\text { n (\%) }\end{array}$ & $\begin{array}{c}\text { Controls } \\
\text { n (\%) }\end{array}$ & $\mathbf{P}^{*}$ & $\mathbf{P} \dagger$ & $P \ddagger$ \\
\hline \multirow{5}{*}{$\begin{array}{l}\text { Genotype for } \\
\text { Asp299Gly }\end{array}$} & $\mathrm{AA}$ & $105(92.9)$ & $26(89.7)$ & $26(92.9)$ & \multirow{5}{*}{1.0} & \multirow{5}{*}{1.0} & \multirow{5}{*}{0.696} \\
\hline & AG & $8(7.1)$ & $3(10.3)$ & $2(7.1)$ & & & \\
\hline & GG & 0 & 0 & 0 & & & \\
\hline & Total & $113(100)$ & $29(100)$ & $28(100)$ & & & \\
\hline & $\begin{array}{l}\text { OR } \\
{[95 \% \mathrm{CI}]}\end{array}$ & $\begin{array}{c}0.99 \\
{[0.20-4.94], \mathrm{p}=0.991}\end{array}$ & $\begin{array}{c}1.50 \\
{[0.23-9.73], p=0.425}\end{array}$ & & & & \\
\hline \multirow{4}{*}{$\begin{array}{l}\text { Alleles of } \\
\text { Asp299Gly }\end{array}$} & A & $218(96.5)$ & $55(94.8)$ & $54(96.4)$ & \multirow{4}{*}{1.0} & \multirow{4}{*}{1.0} & \multirow{4}{*}{0.701} \\
\hline & G & $8(3.5)$ & $3(5.2)$ & $2(3.6)$ & & & \\
\hline & Total & $226(100)$ & $58(100)$ & $56(100)$ & & & \\
\hline & $\begin{array}{l}\text { OR } \\
{[95 \% \mathrm{CI}]}\end{array}$ & $\begin{array}{c}0.99 \\
{[0.20-4.80], \mathrm{p}=0.991}\end{array}$ & $\begin{array}{c}1.47 \\
{[0.24-9.16], p=0.678}\end{array}$ & & & & \\
\hline \multirow{5}{*}{$\begin{array}{l}\text { Genotype } \\
\text { for Thr399Ile }\end{array}$} & CC & $99(90.0)$ & $25(86.21)$ & $24(92.3)$ & \multirow{5}{*}{1.0} & \multirow{5}{*}{0.672} & \multirow{5}{*}{0.516} \\
\hline & CT & $11(10.0)$ & $3(10.34)$ & $2(7.7)$ & & & \\
\hline & TT & 0 & $1(3.44)$ & 0 & & & \\
\hline & Total & $110(100)$ & $29(100)$ & $26(100)$ & & & \\
\hline & $\begin{array}{l}\text { OR } \\
{[95 \% \mathrm{CI}]}\end{array}$ & $\begin{array}{c}1.33 \\
{[0.28-6.42], p=0.720}\end{array}$ & $\begin{array}{c}1.92 \\
{[0.32-11.47], \mathrm{p}=0.474}\end{array}$ & & & & \\
\hline \multirow{4}{*}{$\begin{array}{l}\text { Alleles of } \\
\text { Thr399Ile }\end{array}$} & $\mathrm{C}$ & $209(95.0)$ & $53(91.4)$ & $50(96.2)$ & \multirow{4}{*}{1.0} & \multirow{4}{*}{0.443} & \multirow{4}{*}{0.339} \\
\hline & $\mathrm{T}$ & $11(5.0)$ & $5(8.6)$ & $2(3.8)$ & & & \\
\hline & Total & $220(100)$ & $58(100)$ & $52(100)$ & & & \\
\hline & $\begin{array}{l}\text { OR } \\
{[95 \% \mathrm{CI}]}\end{array}$ & $\begin{array}{c}1.32 \\
{[0.28-6.13], p=0.726}\end{array}$ & $\begin{array}{c}2.36 \\
{[0.44-12.72], \mathrm{p}=0.318}\end{array}$ & & & & \\
\hline
\end{tabular}

A - wild allele of Asp299Gly polymorphism; G - recessive allele of Asp299Gly polymorphism; C - wild allele of Thr399Ile polymorphism; $\mathrm{T}$ - recessive allele of Thr399Ile polymorphism; T2D - type 2 diabetes, OR[95\% CI]- Odds Ratio [95\% Confidence Interval]; $\mathrm{p}^{*}$-T2D vs. controls, $\mathrm{p} \dagger-$ prediabetes vs. controls, $\mathrm{p} \ddagger-\mathrm{T} 2 \mathrm{D}$ vs. prediabetes 
vs. $8.83 \pm 1.73 \%, \mathrm{FPG}=8.08 \pm 2.96$ vs. $8.37 \pm 3.61 \mathrm{mmol} / \mathrm{l}$, $\mathrm{PPG}=8.00 \pm 3.26$ vs. $9.34 \pm 4.34 \mathrm{mmol} / \mathrm{l})$, weight (BMI=32.86 \pm 6.83 vs. $29.96 \pm 6.58 \mathrm{~kg} / \mathrm{m}^{2}$; waist circumference $=103.77 \pm 14.87$ vs. $99.00 \pm 15.62 \mathrm{~cm})$, systolic (134.14 \pm 19.65 vs. $130.00 \pm 17.89 \mathrm{mmHg}$ ) and diastolic blood pressure $(83.33 \pm 9.97$ vs. $79.09 \pm 5.39 \mathrm{mmHg})$.

Taking into consideration the lack of significance in difference between the latter factors, we observed an association between Asp299Gly polymorphism and diabetic retinopathy, diagnosed through fundoscopy. Prevalence of diabetic retinopathy was higher among participants with T2D who also had the heterozygous genotype rather than the homozygous one $(\mathrm{p}=0.033)$. For Thr399Ile polymorphism such difference was not of significance. Both polymorphisms were not associated with prevalence of diabetic polyneuropathy (Table 4).

The mean level of eGFR was the highest in the T2D group, significantly differing from that of the control subjects (Table 2). This was probably related to hyperfiltration in participants with T2D. Within the latter group, the eGFR was not significantly changed depending on presence of both genotypes of both analyzed polymorphisms. Results are detailed in Table 4.

\section{Discussion}

Asp299Gly and Thr399Ile polymorphisms have been associated with a protective role for development of T2D (Kolek et al. 2004) but a predisposing one for metabolic syndrome (Steinhardt et al. 2010; Cuda et al. 2011). The combination of both recessive alleles has even been observed to provide the greatest protection against T2D (Manolakis et al. 2011). However, not all studies confirm such results (Illig et al. 2003; Maldonado-Bernal et al. 2011). A recent metaanalysis showed that neither polymorphism is related to the prevalence of T2D (Yin et al. 2015).

The current results showed a lack of association of the genotyped polymorphisms with both T2D and the prediabetic state in the analyzed sample of a Bulgarian population. The genotype frequency was similar between both cohorts and the analyzed polymorphisms did not seem to alter the risk for the progress of a prediabetic state to T2D, as has been suggested for other genetic variants (Andrulionyte et al. 2006). However, these results could be influenced by the low number of patients included and larger cohort would exclude an association between the polymorphisms and the glucose continuum.

The heterozygous genotypes of both Asp299Gly and Thr399Ile polymorphisms have been found to lower the risk of diabetic neuropathy (Rudofsky et al. 2004). However, Buraczynska et al. (2009) described a predisposing role of the G allele of Asp299Gly to both developments of retinopathy and cardio-vascular disease, but did not confirm an association with other microvascular complications (Buraczynska et al. 2016).

In the current study, it was confirmed that T2D participants with a heterozygous genotype of Asp299Gly

Table 4

TLR4 polymorphisms Asp299Gly and Thr399Ile in relation to chronic complications of T2D

\begin{tabular}{|c|c|c|c|c|}
\hline \multirow{3}{*}{ Complications of T2D } & \multicolumn{4}{|c|}{ Genotype, $\mathrm{n}$ (\% within genotype) } \\
\hline & \multicolumn{2}{|c|}{ Asp299Gly } & \multicolumn{2}{|c|}{ Thr399Ile } \\
\hline & AA & AG & $\mathrm{CC}$ & CT \\
\hline With retinopathy & $7(9.0)$ & $3(42.9)$ & $7(9.7)$ & $3(30.0)$ \\
\hline Without retinopathy & $71(91.0)$ & $4(57.1)$ & $65(90.3)$ & $7(70.0)$ \\
\hline $\mathrm{P}$ & \multicolumn{2}{|c|}{0.033} & \multicolumn{2}{|c|}{0.100} \\
\hline OR $[\mathrm{CI}]$ & \multicolumn{2}{|c|}{$7.61[1.41-41.08], p=0.018$} & \multicolumn{2}{|c|}{$3.98[0.84-18.96], p=0.083$} \\
\hline With polyneuropathy & $80(82.5)$ & $7(87.5)$ & $77(84.6)$ & $9(81.8)$ \\
\hline \multirow[t]{2}{*}{ Without polyneuropathy } & $17(17.5)$ & $1(12.5)$ & $14(15.4)$ & $2(18.2)$ \\
\hline & \multicolumn{2}{|c|}{1.0} & \multicolumn{2}{|c|}{0.682} \\
\hline $\mathrm{OR}[\mathrm{CI}]$ & \multicolumn{2}{|c|}{1.49 [0.17-12.89], $\mathrm{p}=0.719$} & \multicolumn{2}{|c|}{$0.82[0.16-4.20], \mathrm{p}=0.810$} \\
\hline $\operatorname{eGFR}^{*}\left(\mathrm{ml} / \mathrm{min} / 1.73 \mathrm{~m}^{2}\right)$ & $\begin{array}{c}96.47 \pm 26.31 \\
\mathrm{n}=105\end{array}$ & $\begin{array}{c}106.13 \pm 21.61 \\
\mathrm{n}=8\end{array}$ & $\begin{array}{c}96.98 \pm 25.80 \\
\mathrm{n}=99\end{array}$ & $\begin{array}{c}99.82 \pm 22.26 \\
\mathrm{n}=11\end{array}$ \\
\hline $\mathrm{P}$ & \multicolumn{2}{|c|}{0.172} & \multicolumn{2}{|c|}{0.498} \\
\hline
\end{tabular}

A - wild allele of Asp299Gly polymorphism; G - recessive allele of Asp299Gly polymorphism; C - wild allele of Thr399Ile polymorphism; $\mathrm{T}$ - recessive allele of Thr399Ile polymorphism; T2D - type 2 diabetes; OR[CI] - Odds Ration [Confidence Interval]; eGFR - estimated Glomerular Filtration Rate; ${ }^{*}$ Patients with eGFR $<60 \mathrm{ml} / \mathrm{min} / \mathrm{m}^{2}$ were not included in the study. 
had a higher prevalence of diabetic retinopathy, despite that the patients' number was low, as has been shown previously (Buraczynska et al. 2009). However, the polymorphism was not related to the development of polyneuropathy and did not affect the renal function, assessed through eGFR. The current findings were independent of patients' age, duration of the disease, glucose and weight control and arterial blood pressure that could impact progress of chronic complications.

It is mainly Asp299Gly not Thr399Ile polymorphism that leads to modified peptide structure, alters ligand-receptor interaction, post-receptor signaling and further cytokine production (Ferwerda et al. 2008; Ohto et al. 2012; Long et al. 2014). TLR4 actively contributes to the inflammatory response in development of microvascular complications, including diabetic retinopathy (Rajamani and Jialal 2014). The NFkB pathway is stimulated by hyperglycemia, reactive oxygen species, AGEs - all implicated in the pathogenesis of diabetes-associated vascular damage (Forbes and Cooper 2013). It is expected that conformational variants in TLR4, resulting from nucleotide replacement, impact receptor activation and define the subsequent inflammatory response to structural changes in vessel wall. Moreover, the TLR4 signaling pathway, being activated by high-mobility group box1 (HMGB1) - an endogenous TLR ligand, released by necrotic cells, is responsible for the production of a proangiogenic factor for ischemia-induced retinal neovascularization (He et al. 2013). However, whether TLR4 polymorphisms are related to angiogenesis remains to be elucidated.
Taken together, TLR4 polymorphisms may not be crucial for the induction of insulin resistance and glycemic disorders, but their contribution to progress of diabetic complications should not be underestimated. The risk of chronic complications is individual among patients with T2D. The TLR4 gene polymorphisms may be one of the determining factors in their development.

To our knowledge, this is the first study investigating the TLR4 polymorphisms in the glucose continuum. The study has some limitations. The number of participants was low. Gender distribution in prediabetes group differed from that in the other two groups. Diabetic retinopathy was diagnosed by fundoscopy and not fluorescence angiography, considered the gold standard for evaluating the retinal vasculature (Salz and Witkin 2015).

\section{Conclusion}

According to the current study the Asp299Gly and Thr399Ile polymorphisms of TLR4 gene seemed not to be associated with T2D and prediabetes. However, the heterozygous genotype for Asp299Gly polymorphism appeared to define an increased risk for diabetic retinopathy - a major disabling complication of diabetes.

\section{Acknowledgments}

The study was financially supported by Medical University-Sofia GRANT project №32-D/2013.

\section{References}

American Diabetes Association. Classification and diagnosis of diabetes. Diabetes Care 33(Suppl 1), S62-S69, 2010.

Andrulionyte L, Peltola P, Chiasson JL, Laakso M, STOP-NIDDM Study Group. Single nucleotide polymorphisms of PPARD in combination with the Gly482Ser substitution of PGC-1A and the Pro12Ala substitution of PPARG2 predict the conversion from impaired glucose tolerance to type 2 diabetes: the STOP-NIDDM trial. Diabetes 55, 2148-2152, 2006.

Arbour NC, Lorenz E, Schutte BC, Zabner J, Kline JN, Jones M, Frees K, Watt JL, Schwartz DA. TLR4 mutations are associated with endotoxin hyporesponsiveness in humans. Nat Genet, 25, 187-191, 2000.

Bagarolli RA, Saad MJ, Saad ST. Toll-like receptor 4 and inducible nitric oxide synthase gene polymorphisms are associated with Type 2 diabetes. J Diabetes Complications 24, 192-198, 2010.

Buraczynska M, Baranowicz-Gaszczyk I, Tarach J, Ksiazek A. Toll-like receptor 4 gene polymorphism and early onset of diabetic retinopathy in patients with type 2 diabetes. Hum Immunol 70, 121-124, 2009.

Buraczynska M, Zukowski P, Ksiazek K, Wacinski P, Dragan M. The effect of toll-like receptor 4 gene polymorphism on vascular complications in type 2 diabetes patients. Diabetes Res Clin Pract 116, 7-13, 2016.

Cuda C, Badawi A, Karmali M, El-Sohemy A. Polymorphisms in Toll-like receptor 4 are associated with factors of the metabolic syndrome and modify the association between dietary saturated fat and fasting high-density lipoprotein cholesterol. Metabolism 60, 1131-1135, 2011.

Dasu MR, Devaraj S, Zhao L, Hwang DH, Jialal I. High glucose induces toll-like receptor expression in human monocytes: mechanism of activation. Diabetes 57, 3090-3098, 2008. 
Dasu MR, Devaraj S, Park S, Jialal I. Increased toll-like receptor (TLR) activation and TLR ligands in recently diagnosed type 2 diabetic subjects. Diabetes Care 33, 861-868, 2010.

Devaraj S, Dasu MR, Rockwood J, Winter W, Griffen SC, Jialal I. Increased toll-like receptor (TLR) 2 and TLR4 expression in monocytes from patients with type 1 diabetes: further evidence of a proinflammatory state. J Clin Endocrinol Metab 93, 578-583, 2008.

Fernandez-Real JM, Gutierrez C, Ricart W, Casamitjana R, Fernandez-Castaner M, Vendrell J, Richart C, Soler J. The TNFalpha gene Nco I polymorphism influences the relationship among insulin resistance, percent body fat, and increased serum leptin levels. Diabetes 46, 1468-1472, 1997.

Ferwerda B, McCall MB, Verheijen K, Kullberg BJ, van der Ven AJ, Van der Meer JW, Netea MG. Functional consequences of toll-like receptor 4 polymorphisms. Mol Med 14, 346-352, 2008.

Festa A, D’Agostino R, Howard G, Mykkanen L, Tracey RP, Haffner SM. Chronic subclinical inflammation as part of the insulin resistance syndrome: the Insulin Resistance Atherosclerosis Study (IRAS). Circulation 101, 42-47, 2000.

Forbes JM, Cooper ME. Mechanisms of diabetic complications. Physiol Rev 93, 137-188, 2013.

He C, Sun Y, Ren X, Lin Q, Hu X, Huang X, Su SB, Liu Y, Liu X. Angiogenesis mediated by toll-like receptor 4 in ischemic neural tissue. Arterioscler Thromb Vasc Biol 33, 330-338, 2013.

Hoffstedt J, Andersson IL, Persson L, Isaksson B, Arner P. The common -675 4G/5G polymorphism in the plasminogen activator inhibitor-1 gene is strongly associated with obesity. Diabetologia 45, 584-587, 2002.

Illig T, Bongardt F, Schopfer A, Holle R, Muller S, Rathmann W, Koenig W, Meisinger C, Wichmann HE, Kolb H; KORA Study Group. The endotoxin receptor TLR4 polymorphism is not associated with diabetes or components of the metabolic syndrome. Diabetes 52, 2861-2864, 2003.

Illig T, Bongardt F, Schopfer A, Muller-Scholze S, Rathmann W, Koenig W, Thorand B, Vollmert C, Holle R, Kolb H, Herder C; Kooperative Gesundheitsforschung im Raum Augsburg/Cooperative Research in the Region of Augsburg. Significant association of the interleukin-6 gene polymporphism C-174G and A- 598G with type 2 diabetes. J Clin Endocrinol Metab 89, 5053-5058, 2004.

Kawasaki T, Kawai T. Toll-like receptor signaling pathways. Front Immunol 5, 461, 2014.

Kolek MJ, Carlquist JF, Muhlestein JB, Whiting BM, Horne BD, Bair TL, Anderson JL. Toll-like receptor 4 gene Asp299Gly polymorphism is associated with reductions in vascular inflammation, angiographic coronary artery disease, and clinical diabetes. Am Heart J 148, 1034-1040, 2004.

Long H, O’Connor BP, Zemans RL, Zhou X, Yang IV, Schwartz DA. The Toll-like receptor 4 polymorphism Asp299Gly but not Thr399Ile influences TLR4 signaling and function. PLoS One 9, e93550, 2014.

Maldonado-Bernal C, Trejo-de la O A, Sanchez-Contreras ME, Wacher-Rodarte N, Torres J, Cruz M. Low frequency of Toll-like receptors 2 and 4 gene polymorphisms in Mexican patients and their association with type 2 diabetes. Int J Immunogenet 38, 519-523, 2011.

Manolakis AC, Kapsoritakis AN, Tiaka EK, Sidiropoulos A, Gerovassili A, Satra M, Vamvakopoulou D, Tsiopoulos F, Papanas N, Skoularigis I, Potamianos SP, Vamvakopoulos N. TLR4 gene polymorphisms: evidence for protection against type 2 diabetes but not for diabetes-associated ischaemic heart disease. Eur J Endocrinol 165, 261-267, 2011.

Miller SA, Dykes DD, Polesky HF. A Simple salting out procedure for extracting DNA from human nucleated cells. Nucleic Acids Res 16, 1215, 1998.

Noreen M, Shah MA, Mall SM, Choudhary S, Hussain T, Ahmed I, Jalil SF, Raza MI. TLR4 polymorphisms and disease susceptibility. Inflamm Res 61, 177-188, 2012.

Nyati KK, Prasad KN, Verma A, Singh AK, Rizwan A, Sinha S, Paliwal VK, Pradhan S. Association of TLR4 Asp299Gly and Thr399Ile polymorphisms with Guillain-Barre' syndrome in Northern Indian population. J Neuroimmunol 218, 116-119, 2010.

Ohto U, Yamakawa N, Akashi-Takamura S, Miyake K, Shimizu T. Structural analyses of human Toll-like receptor 4 polymorphisms D299G and T399I. J Biol Chem 287, 40611-40617, 2012.

Rajamani, U, Jialal I. Hyperglycemia Induces Toll-like receptor-2 and -4 expression and activity in human microvascular retinal endothelial cells: implications for diabetic retinopathy. J Diabetes Res 2014, 790902, 2014.

Rosmond R, Chagnon M, Bouchard C, Bjorntorp P. Increased abdominal obesity, insulin and glucose levels in nondiabetic subjects with a T29C polymorphism of the transforming growth factor-betal gene. Horm Res 59, 191-194, 2003.

Rudofsky G Jr, Reismann P, Witte S, Humpert PM, Isermann B, Chavakis T, Tafel J, Nosikov VV, Hamann A, Nawroth P, Bierhaus A. Asp299Gly and Thr399Ile genotypes of the TLR4 gene are associated with a reduced prevalence of diabetic neuropathy in patients with type 2 diabetes. Diabetes Care 27, 179-183, 2004. 
Salz DA, Witkin AJ. Imaging in diabetic retinopathy. Middle East Afr J Ophthalmol 22, 145-150, 2015.

Shi H, Kokoeva MV, Inouye K, Tzameli I, Yin H, Flier JS. TLR4 links innate immunity and fatty acid-induced insulin resistance. J Clin Invest 116, 3015-3025, 2006.

Spranger J, Kroke A, Mohlig M, Hoffman K, Bergman MM, Ristow M, Boeing H, Pfeiffer AF. Inflammatory cytokines and the risk to develop type 2 diabetes: results of the prospective population-based European Prospective Investigation into Cancer and Nutrition (EPIC) - Potsdam study. Diabetes 52, 812-817, 2003.

Steinhardt AP, Aranguren F, Tellechea ML, Gomez Rosso LA, Brites FD, Martinez-Larrad MT, Serrano-Rios M, Frechtel GD, Taverna MJ. A functional nonsynonymous toll-like receptor 4 gene polymorphism is associated with metabolic syndrome, surrogates of insulin resistance, and syndromes of lipid accumulation. Metabolism 59, 711-717, 2010.

Weintrob N, Amitay I, Lilos P, Shalitin S, Lazar L, Josefsberg Z. Bedside neuropathy disability score compared to quantitative sensory testing for measurement of diabetic neuropathy in children, adolescents, and young adults with type 1 diabetes. J Diabetes Complications 21, 13-19, 2007.

Weyrich P, Staiger H, Stancakova A, Machicao F, Machann J, Schick F, Stefan N, Kuusisto J, Laakso M, Schafer S, Fritsche A, Haring HU. The D299G/T399I Toll-like receptor 4 variant associates with body and liver fat: results from the TULIP and METSIM Studies. PLoS One 5, e13980, 2010.

Wolford JK, Gruber JD, Ossowski VM, Vozarova B, Antonio Tataranni P, Bogardus C, Hanson RL. A C-reactive protein promoter polymorphism is associated with type 2 diabetes mellitus in Pima Indians. Mol Genet Metab 78, 136-144, 2003.

Yang Z, Chen R, Zhang Y, Huang Y, Hong T, Sun F, Ji L, Zhan S. Scoring systems to screen for diabetic peripheral neuropathy. Cochrane Database of Systematic Reviews 3, CD010974, 2014.

Yin YW, Wang Q, Sun QQ, Hu AM, Liu HL. Toll-like receptor 4 gene Asp299Gly and Thr399Ile polymorphisms in type 2 diabetes mellitus: a meta-analysis of 15,059 subjects. Diabetes Res Clin Pract 107, 338-347, 2015. 